\title{
CONDITIONAL SENTENCE LEARNING USING GAME AS AN INSTRUCTIONAL MEDIUM IN COVID-19 PANDEMIC
}

\author{
Fitria Aftinia ${ }^{1}$ \\ Dwi Angga Dewantoro \\ Teacher of Muhammadiyah Senior High School Surabaya \\ niafa13@gmail.com
}

\begin{abstract}
The purpose of this study is to know the effectiveness of using game at the students' learning outcome for Conditional Sentence material. This study is an experimental study using One-Group Pre-test and Post-test Design. The data are the students' learning outcomes and responses on the questionnaire. The study was conducted in SMA Muhammadiyah 9 Surabaya. The questionnaire and pre-test were carried out before learning. After online learning using game as an instructional medium, post-test and questionnaire were given to students. The learning outcome scores were analyzed with the help of the SPSS program to determine the increase in learning outcomes and the level of completeness. The conclusion is that learning Conditional Sentences with instructional medium for computer-assisted games on online learning shows effectiveness. The effectiveness of learning is shown by having achieved the completeness of the learning outcomes and students giving good responses to the use of games as an instructional medium during the Covid-19 pandemic.
\end{abstract}

Keywords: covid-19 pandemic, game, online learning

\section{INTRODUCTION}

The corona virus has caught the world's attention in early 2020. According to WHO, Covid-19 (Coronavirus 2019) is declared as public health emergency which has become the center of international attention as many as more than 200 countries have been affected by the corona virus outbreak, including Indonesia (World Health Organization, 2020). The Covid-19 pandemic has been identified since March 2, 2020 in Indonesia and continues to increase its spread (Wibowo \& Yurianto, 2020). This pandemic affects educational field as well. Therefore, it leads to online teaching and learning activities because it can be used at any time without any time limit. In the context of online learning, students can connect directly with the teacher to access the material (Dewi, et al., 2020).

The data obtained on learning English in a number of schools seem less attractive, to the point that students feel bored in the process of learning English and the class atmosphere tends to be passive. Such conditions lead to boredom

\section{British, Jurnal Bahasa dan Sastra Inggris}


and irritation so that the interest, attention and encouragement of students in the learning process become bad (Ristiyani \& Bahriah, 2016). The creativity of a teacher in the online learning process seems to really have an impact on the success of a learning target.

To reduce the number of Covid-19 sufferers, the central government, provincial governments and local governments have produced policies in the world of education, namely temporarily eliminating face-to-face learning and replaced with online learning at both the school and college levels (Pujilestari, 2020). Based on a questionnaire from a high school English teacher, it was also a problem that the English material was difficult to understand, thus increasing the burden on the teacher in explaining English material. With this pandemic, students are required to learn from home which results in having difficulty for teachers in finding the right methods and media to explain the material so the students can understand. Since the difficulties faced by these students, instructional media that are suitable and liked by students are needed. Lutfi, et al. (2019) state that games as instructional media create happy atmosphere so the students feel happy.

In the regulation of the minister of education and culture of the Republic of Indonesia number 65 of 2013, it is stated that the learning process in the education unit is held in an interactive, inspirational, fun, challenging manner, motivating students to participate actively and providing sufficient space for initiative, creativity, and independence according to their talents, interest and physical and psychological development of students. When someone has physical limitations, it will require more effort to interact socially with other people. Certainly this also has an impact on the instructional media that will be used during the teaching and learning process.

The initial data on students who were asked for an opinion showed that $93 \%$ of them liked playing every time and those who said they played games once in a month were $0 \%$, meaning that most of the students like playing games. It is presented in Figure 1.

\section{British, Jurnal Bahasa dan Sastra Inggris}




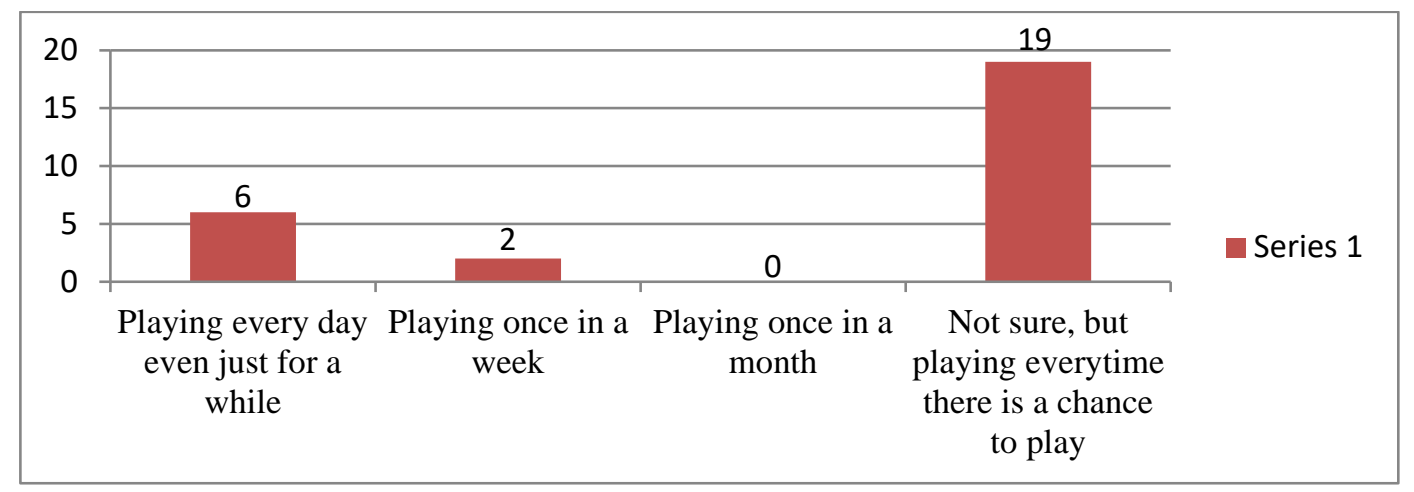

Figure 1. The Frequency of Students Playing

Based on the results of questionnaire that has been carried out in SMA Muhammadiyah 9 Surabaya, online learning has been running for a semester. The implementation of online learning in SMA Muhammadiyah 9 Surabaya shows that the students asked their friends and learned on their own when encountering problems in learning English. Both statements got the same score which was 50\%. Therefore, the teacher must provide wider opportunities for students so the students bravely ask the teacher. Regarding English skills or components that are not mastered by the students, the results of the questionnaire shows that $53 \%$ of students experience the most difficulty in the grammar field. While $38 \%$ of them stated that pronunciation is another English component that is hard to master. Therefore, the teacher must give more emphasis to learning English in the fields of grammar and pronunciation. Regarding the facilities available and beneficial during activities on online learning, $96 \%$ of students stated that they have cell phones or Smartphone. Others (84\%) stated that quota or starter pack for prepaid SIM card that the school provided is helpful for them.

Games often require students to use problem-solving skills and the ability to come up with a solution. The advantage of playing games as instructional media is that it is very entertaining and fun. Games allow active participation of students, provide direct feedback, apply concepts and they are flexible and easy to make and reproduce (Sadiman, 2014). Games can offer many opportunities for students to learn, both knowledge about science, related vocabulary in an interesting way (Hilmiyah \& Lutfi, 2017). Based on the national education standards (BSNP) as contained in the paradigm of national education as a democratic, game-nuanced, 
openness, challenging, responsible sense of training, it will stimulate students to come to school or to campus because they are happy not because they are forced (BSNP, 2010). Games as instructional media can help students learn independently and create a creative atmosphere for students.

Games can be linked to learning experiences through appropriate design. Game strategies used in education include scenario, matching, challenging and problem solving, so game-based learning allows students to build knowledge from ambiguity, trial and error and assimilating new knowledge (Nordby, et al., 2016). The use of games can be used to seduce and motivate students to achieve certain goal, in this case the planned learning objectives are called gamification (Carrillo, et al., 2019). It is necessary to do research on games as media for learning English during distance learning in Covid-19 pandemic.

The results of a study by Lutfi and Nugroho (2019) show that learning by using games as instructional media can improve learning outcomes and students' motivation. It is supported by Ling (2018) who stated that gamification has a high potential for increasing students' intrinsic motivation. Therefore, it is necessary to do a study on the use of Smartphone and computer assisted games as media for learning English during the pandemic with online learning.

This study was conducted for the first time in this school. So far, learning English in this schoolnever uses computer-based games. This study was done during online learning. Compared to others, this study uses the game specially developed for Conditional Sentence learning. It can overcome the boredom studying at home. Students have freedom to learn that is not bound by time and place.

Based on the description above, it is necessary to conduct a study on the effectiveness of conditional sentences learning by using game as an instructional medium to improve grammar competence in an atmosphere of the Covid-19 pandemic. Effectiveness is based on the learning outcomes achieved. Besides, the responses of students after learning by using games as instructional media are taken into account as well.

\section{British, Jurnal Bahasa dan Sastra Inggris}




\section{RESEARCH METHOD}

The study use dpre-experimental design. It was conducted in Class XI of SMA Muhammadiyah 9 Surabaya in academic year 2020-2021. The learning was taught by using a computer game.The game was developed purposely for Conditional Sentences learning. The game entitled "CS Senior High School" has gone through a feasibility test so it can be used as an instructional medium (Aftinia, 2017).Pretest was given before the learning. After pre-test, the students learned English using the game given. The post-test and questionnaire were given after the learning. The study was conducted from August to December in 2020 online.

The design of the study used is One-Group Pre-test and Post-test Design shown as follows. According to Sugiyono (2013), One-Group Pretest-Posttest Design needs pre-test before the treatment so the condition before and after the treatment can be compared.

$\mathrm{O}_{1} \quad \mathrm{X} \quad \mathrm{O}_{2}$

Information:

$\mathrm{O}_{1}$ Pre-test

$\mathrm{O}_{2}$ Post-test

$\mathrm{X}$ Learning using Game as an Instructional Medium

The learning outcomes were tested on mean between the pre-test and post-test scores, processed with the help of the SPSS program. The classical completeness level of the pre-test and post-test scores based on the criteria reach $70 \%$ achieving individual completeness and classical completeness is determined when it reaches $80 \%$ complete while the questionnaire in the form of Gutman scale was analyzed with quantitative descriptions.

Classical completeness determination is using the following formula.

$$
\text { Classical completeness }=\frac{\Sigma \text { students complete }}{\Sigma \text { total } \text { students }} \times 100 \%
$$

It is declared effective if there is an increase in classical completeness and the post-test score reaches classical completeness equal to or greater than $80 \%$. 
The calculation of the questionnaire score results with the number one if you answer 'yes' and zero if you answer 'no', the percentage is calculated and categorized as in Table 1 (Riduwan, 2015). It can be stated effective if it is categorized as good or very good.

Table 1. The Criteria of Questionaire Response

\begin{tabular}{lcc} 
No & Percentage & Category \\
\hline 1 & $81 \%-100 \%$ & Very Good \\
\hline 2 & $61 \%-80 \%$ & Good \\
\hline 3 & $41 \%-60 \%$ & Sufficient \\
\hline 4 & $21 \%-40 \%$ & Bad \\
\hline 5 & $0 \%-20 \%$ & Very Bad
\end{tabular}

\section{RESEARCH FINDING AND DISCUSSION}

\section{The students' learning outcomes}

The material of the tests is Conditional Sentences. Learning outcome tests are arranged based on indicators according to Basic Competency (KD) of senior high school. The results of the pre-test and post-test scores are presented as follows.

Table 2. Pre-test and Post-test Scores

\begin{tabular}{lccccc}
\multicolumn{1}{c}{ Condition } & Total & Mean & Lowest score & $\begin{array}{c}\text { Highest } \\
\text { score }\end{array}$ & $\begin{array}{c}\text { Completeness } \\
(\%)\end{array}$ \\
\hline Pre-test Score & 26 & 27.884 & 5 & 85 & 3.846 \\
\hline Post-test & 26 & 76.538 & 40 & 100 & 92.307
\end{tabular}

Score

According to Table 2, it shows that there is an increase of mean, from pre-test score 27.884 to post-test score 76.538 and there is an increase in classical completeness, namely $3.846 \%$ to $92.307 \%$. These results indicate that learning Conditional Sentences by using "CS Senior High School" game as an instructional medium can improve classical completeness. These results are in accordance with the opinion of Adnan, et al., (2017)which state that the game can be said to be successful in improving student learning outcomes. Besides, the use of attractive learning media can create an effective learning atmosphere and improve learning outcomes.

To find out whether there was a significant difference between the mean of pre-test score and the post-test score, paired t-test was carried out. The normality

\section{British, Jurnal Bahasa dan Sastra Inggris}


test was carried out first as a paired t-test requirement. The results obtained by SPSS are presented in Table 3.

Table 3. The Result of Paired t-test

\begin{tabular}{llcccccc} 
Score & $\begin{array}{c}\sum_{\text {Students }} \\
\end{array}$ & Mean & Sig & $\begin{array}{c}\text { t count } \\
\text { pair }\end{array}$ & Df & $\begin{array}{c}\text { t-table } \\
\text { price } \\
\mathbf{( 5 \% )}\end{array}$ & Conclusion \\
\hline pre-test & 26 & 27.884 & 0.680 & & & & \\
\hline post-test & 26 & 76.538 & 0.220 & -12.206 & 25 & 2,06 & $\begin{array}{c}\text { Ho } \\
\text { Rejected }\end{array}$
\end{tabular}

To test for normality Kolmogorov-Smirnov Test was conducted with the help of the SPSS program. The Kolmogorov-Smirnov Test price with a sig at a pre-test score of 0.680 and a post-test sig price of 0.220 , both of which are greater than 0.05 , meaning that the pre-test and post-test scores are normally distributed. The results of the normality test show that paired t tests can be done. The result of $t$ count pair is 12.206 with t table 2.06 shows that $\mathrm{t}$ count is greater than $\mathrm{t}$ table means the results above indicate that there is a significant difference between the pre-test score and the post-test score. This is in accordance with the result of Syahril's and Linda's (2020) study in which students' scores are significantly different between pre-test and post-test when game is used as an instructional medium.

Learning using games has a positive impact based on the learning outcomes obtained. This is the same as expressed by Arsyad (2009), namely improving process and achievement can use learning media for clarity of information presentation. Students feel happy about learning using computer-based games (Sugiyono, 2013). The use of games during learning can solve the problems of students in understanding the material (Riduwan, 2015).

The result of learning can be seen from the learning outcomes. It is accordance with the research from Nikmah (2019) stating that learning outcomes are important things that become benchmarks for the success of teachers in the learning process. The use of tests is carried out to test the learning outcomes of students. During online learning, teachers are limited to express and they tend to give assignments only. This can demotivate students and make them less 
interested. An unattractive learning atmosphere can be circumvented by using creative media (Sugiyono, 2013), one of which is computer-assisted games.

Based on the aforementioned result, it can be interpreted that learning English especially in Conditional Sentences material using game as an instructional medium can improve learning outcomes. Moreover, it can achieve classical completeness as determined by the school. It is accordance with Andiastutik's and Lutfi's (2017) statement that is the use of computer-based games as instructional media for lessons is able to achieve learning well.

The game used in this research was an offline computer game. The file of the game can be shared via Google Drive. It was developed purposely for Conditional Sentence learning and entitled "CS Senior High School" (Aftinia, 2017). The students as the players follow the storyline in which they encounter some conversations with other characters in the game. The dialogue can be played and listened by the players many times because the "back" button available in the game allows them to do so. In the middle and at the end of the game the students are given chance to do exercise about Conditional Sentences.

\section{The students' responses}

The questionnaires were given to the students after the learning. It was conducted to get responses on the use of game as an instructional medium. The results of the game use can be elaborated as follows (Table 4).

Table 4. The Result of Students' Questionnaire

\begin{tabular}{|c|c|c|c|c|}
\hline No & Statements & Agree & Disagree & \% Agree \\
\hline 1 & The way to play the game is interesting. & 23 & 3 & $88.46 \%$ \\
\hline 2 & $\begin{array}{l}\text { The game instruction is easy to } \\
\text { understand. }\end{array}$ & 19 & 7 & $73.07 \%$ \\
\hline 3 & I want to play the game again. & 18 & 8 & $69.23 \%$ \\
\hline 4 & $\begin{array}{l}\text { I am happy to learn English if the game } \\
\text { like this is used. }\end{array}$ & 20 & 6 & $76.92 \%$ \\
\hline 5 & $\begin{array}{l}\text { I do not want to fail in finishing the } \\
\text { mission in the game. }\end{array}$ & 22 & 4 & $84,61 \%$ \\
\hline 6 & $\begin{array}{l}\text { If I fail, I want to replay to be } \\
\text { successful. }\end{array}$ & 19 & 7 & $73.08 \%$ \\
\hline 7 & $\begin{array}{l}\text { I want to play the game continuously } \\
\text { during the Covid-19 pandemic. }\end{array}$ & 21 & 5 & $80.76 \%$ \\
\hline 8 & $\begin{array}{l}\text { I don't feel bored if the game as a } \\
\text { medium is used in learning. }\end{array}$ & 23 & 3 & $88.46 \%$ \\
\hline 9 & The game is fun and interesting to learn & 24 & 2 & $92.31 \%$ \\
\hline
\end{tabular}

\section{British, Jurnal Bahasa dan Sastra Inggris}




\begin{tabular}{lllll} 
No & \multicolumn{1}{c}{ Statements } & Agree & Disagree & \% Agree \\
\hline & during the Covid-19 pandemic. & & & \\
\hline 10 & $\begin{array}{l}\text { Learning English by using the game as } \\
\text { a medium can motivate me to continue } \\
\text { learning while at home. }\end{array}$ & 20 & 6 & $76.92 \%$ \\
\hline 11 & $\begin{array}{l}\text { The game really helps me to understand } \\
\text { English especially Conditional } \\
\text { Sentences material. }\end{array}$ & 22 & 4 & $84.61 \%$
\end{tabular}

The results of the questionnaire above show the percentage above $61 \%$ which means that it is categorized as good and very good. There is no single statement that gets the category of being poor or very poor. This means that students are interested in using the game as an instructional medium for the topic of Conditional Sentences. In the aspect of ease of execution as outlined in statements 1 and 2 shows the percentages of $88.46 \%$ and $70.07 \%$ these results fall into very good and good categories, meaning that students find the game easy to use.

In the pleasant aspect stated in statements number 3,4 , and 5 got a percentage of $69.23 \%, 76.92 \%$, and $84.61 \%$, these results show that statements number 3 and 4 are in good category and in reality 5 is in the very good category. Students are eager to play, happy with the games used, and trying to be successful in playing. These results indicate that the game can make students happy to learn. This result is in accordance with Lutfi's, et al. (2019) opinion.

In the aspect of encouraging learning, data were obtained as much as $73.08 \%$, $80.76 \%$, and $88.46 \%$ including the good and very good categories. These results can indicate that during the pandemic with online learning students feel the desire to continue playing and learning with the game as a medium for learning English. This result is in accordance with Zeng, et al. (2020) who state that educational games can make learning more attractive and effective

In the aspect of the desire to continue learning as outlined in statements number 9,10 , and 11 , the results obtained are $92.31 \%, 76.92 \%$, and $84.61 \%$ responses, which means they are categorized as good and very good. Very good category is found in statements number 9 and 11 . This means that students feel fun and the game is interesting to learn. Besides, this game really helps them to 
understand English. This result is in accordance with the Lutfi's and Nugroho's (2019) opinion and also in accordance with the research results of the researchers.

The scores of learning outcomes show that there has been an increase in learning outcomes and it has achieved completeness on the post-test score. Besides, the questionnaire shows students find it easy to play games and learning can be fun. In addition, students want to continue learning even though they learn at home.

\section{CONCLUSION AND SUGGESTIONS}

Based on the data obtained and the discussion, the conclusion is learning Conditional Sentences with instructional media for computer-assisted game on online learning shows effectiveness. The effectiveness of learning is shown by having achieved the completeness of the learning outcomes and students giving good responses to the use of games as an instructional medium during the Covid19 pandemic. These results can be used as an alternative to English teachers in overcoming online learning that makes students bored because of staying too long at home. It is suggested that instructions for using game can be made clearer in oral to students before the learning. For the next research, it is suggested to use game in English learning designed for Android mobile phone because students are more comfortable using mobile phone than laptop.

\section{REFERENCES}

Adnan, F., Prasetyo, B., \& Nuriman, N. 2017. Usability Testing Analysis on The Bana Game as Education Game Design References on Junior High School. Jurnal Pendidikan IPA Indonesia, 6(1), 88-94.

Aftinia, F. 2017. The Development of A Computer-Based Instructional Medium to Teach Conditional Sentences to Eleventh Graders, Malang: State University of Malang.

Andiastutik, E., \& Lutfi, A. 2017. Pengembangan Permainan Diamons Chemistry Adventure sebagai Media Pembelajaran Pada Materi Pokok Hidrokarbon Kelas XI SMA. Unesa Journal of Chemical Education, 6(2), 212-218.

Arsyad, A. 2009. Media Pembelajaran. Depok: RajaGrafindo Persada.

BSNP. 2010. Laporan BSNP. Jakarta. Retrieved from https://www.bsnpindonesia.org/id/wp-content/uploads/2012/04/Laporan-BSNP-2010.pdf

\section{British, Jurnal Bahasa dan Sastra Inggris}


Carrillo, D. L., García, A., Laguna, T., Magán, G. R., \& Moreno, J. A. 2019.

Using Gamification in a Teaching Innovation Project at the University of Alcalá: A New Approach to Experimental Science Practices. The

Electronic Journal of e-Learning, 17(2), 93-106. doi:10.34190/jel.17.2.03

Dewi, C. A., Kurniasih, Y., \& Khery, Y. 2020. Pelatihan Pembuatan Media Pembelajaran Online Bagi Guru di SMPN 1 Batulayar Kabupaten Lombok Barat. Jurnal Pengabdian Kepada Masyarakat, 5(1).

Hilmiyah, N. F. \& Lutfi, A. 2017. Pengembangan Permainan Chebo Collect Sebagai Media Pembelajaran Pada Materi Pokok Ikatan Kimia Untuk Kelas X Sma. UNESA Journal of Chemical Education, 6(2).

Ling, L. T. 2018. Meaningful Gamification and Students' Motivation: A Strategy for Scaffolding Reading Material. Online Learning, 22(2), 141-155. doi:10.24059/olj.v22i2.1167

Lutfi, A. \& Nugroho, A. 2019. Minat Belajar dan Keberhasilan Belajar Partikel Penyusun Atom Dengan Media Pembelajaran Permainan Chem Man. Jurnal Pembelajaran Kimia OJS, 4(1), pp. 39-50.

Lutfi, A., Suyono, Erman, \& Hidayah, R. 2019. Edutainment With Computer Game As A Chemistry Learning Media. Jurnal Penelitian Pendidikan Sains (JPPS) Pascasarjana Unesa Surabaya, 8(2).

Nikmah, C. 2019. Pengembangan Perangkat Pembelajaran Model Argument Driven Inquiry (ADI) untuk Meningkatkan Self Efficacy dan Hasil Belajar Siswa pada Materi Larutan Elektrolit dan Non-Elektrolit. Pendidikan Sains. Surabaya: Universitas Negeri Surabaya.

Nordby, A., Øygardslia, K., Sverdrup, U. \& Sverdrup, H. 2016. The art of Gamification; Teaching Sustainability and System Thinking by Pervasive Game Development. The Electronic Journal of e-Learning, 14(3), pp. 152168.

Pujilestari, Y. 2020. Dampak Positif Pembelajaran Online Dalam Sistem Pendidikan Indonesia Pasca Pandemi Covid-19. 'Adalah: Buletin Hukum dan Keadilan, 4(1), pp. 49-56.

Riduwan. 2015. Skala Pengukuran Variabel-Variabel Penelitian. Bandung: Alfabeta.

Ristiyani, E. \& Bahriah, E. S. 2016. Analisis Kesulitan Belajar Kimia Siswa di SMAN X Kota Tangerang Selatan. Jurnal Penelitian dan Pembelajaran IPA, 2(1), pp. 18-29.

Sadiman, A.S. 2014. Media Pendidikan Pengertian, Pengembangan, dan Pemanfaatannya. Depok: PT. Raja Grafindo Persada. 
Sugiyono. 2013. Metode Penelitian Kuantitatif, Kualitatif, dan $R \& D$. Bandung: Alfabeta.

Syahril, \& Linda, F. R. 2020. The Influence of Puzzle Picture Games Media in Improving Learning Outcomes in Thematic Learning in Class IV MIN, Solok City. Social Sciences, Education and Humanities (GCSSSEH).6, pp. 321-329. Padang: Redwhite Press. doi:https://doi.org/10.32698/GCSPSSHERS346

Wibowo, B. \& Yurianto, A. 2020. Pedoman Pencegahan dan Pengendalian Coronavirus Disease (Covid-19). [Online] Available at: https://repository.ugm.ac.id/276196/1/Pedoman\%20Pencegahan\%20dan\% 20Pengendalian\%20Coronavirus\%20Disease $\% 20 \% 28$ COVID19\%29\%20-\%20Kemenkes.pdf

World, H. O. 2020. WHO Coronavirus Disease (COVID-19) Dashboard. [Online] Available at: https://covid19.who.int/?gclid=EAIaIQobChMI682d0z07QIV2X4rCh3_YA2YEAAYASAAEgIZaPD_BwE

[Accessed 20 December 2020].

Zeng, J., Parks, S., \& Shang, J. 2020. To Learn Scientifically, Effectively, and Enjoyably: A Review of Educational Games. Hum Behav \& Emerg Tech(2), 186-195. doi:https://doi.org/10.1002/hbe2.188ZENG ET AL. 195 